查ヨ受ケシメル。同時二口腔衛生ヨ充分二等ラシメル。第一八洗ロデアル、之入食後、外 出ヨリ歸宅後必ズ行バシメル。用フルモノハ「ローション」「オドール】ス之二類ズルモ

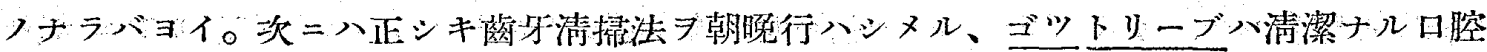

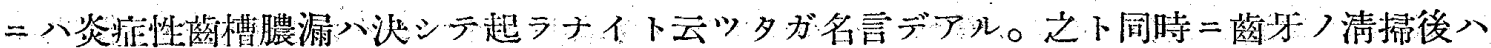

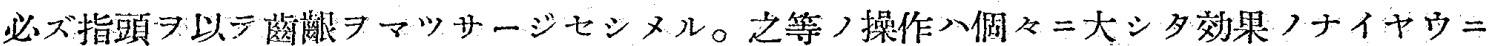
思冈レルモノデアルガ、患者ヨシテ常ニロ腔＝注意フ向アシメルト云フ點デ甚ダ效果ガア ルハデアル。

（本篇八昭和七年十月二日、九州落科學會第一回總會二於ケ几檜垣教授ノ御講演ノ大要ナり。）

\title{
顎及ビ顎周急性化膿性炎, 原因的考察
}

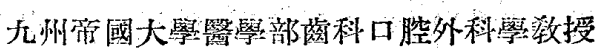

\section{醫䐴博士 問 田亮 次}

\section{Beobachtungen über die Ursachen der akuten eitrigen}

Entzündungen am Kiefer und soine Umgebung.

Von Prof. Dr. med. Ryoji Toida.

(Direktor der Univ-.Zahn-,und Mundchirurgie-Klinik zu Fukuoka.)

Vorgetragen am 2 ten Oktober 1932 in der ersten Generalsitzung der

Zahnärztlichen Gesellschaft zu Kyushu. Fukuoka. Japan.

私ガ今日マデ約十ラ年以上つ經驗ニヨリマス卜顎骨々髓炎骨膜炎等つ如キ化膿性急性炎

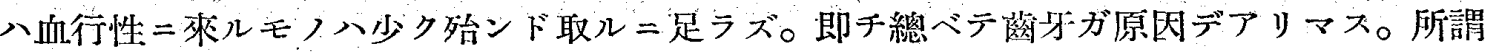

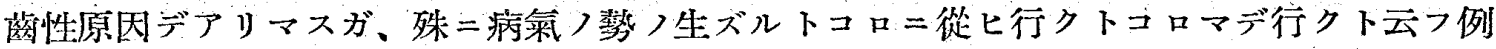
ガ多イノデアリマス。ソコデ顎自體又八其ノ周園つ化膿性炎ノ原因八病菌ニヨリ不可抗力。

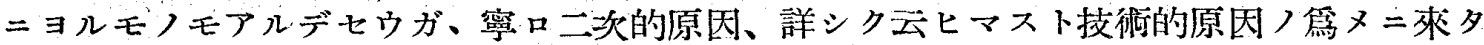
卜思ハレルモノガ非常二多イ㴝二思ハレマス。

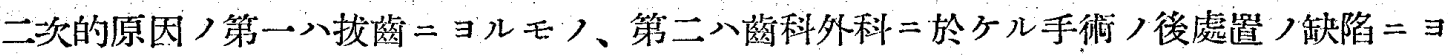

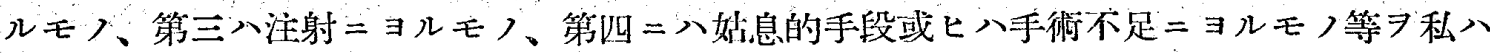
二次的原因卜考へテ居りマス。

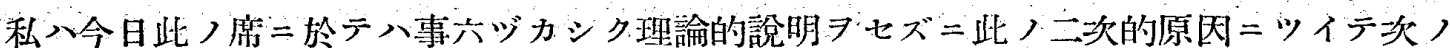
如キ例フ擧ゲテオ話シシタイト思ヒマス。

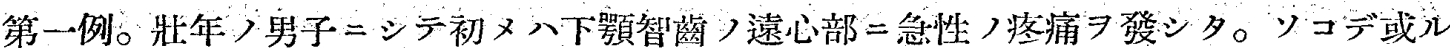

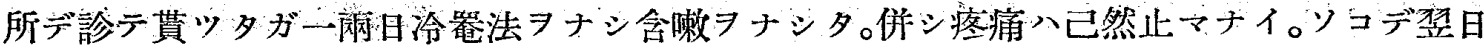

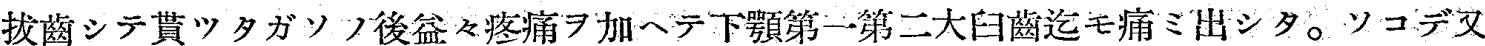

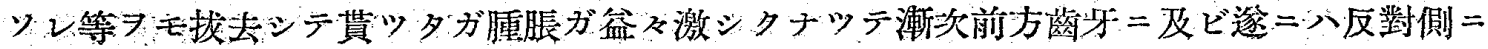




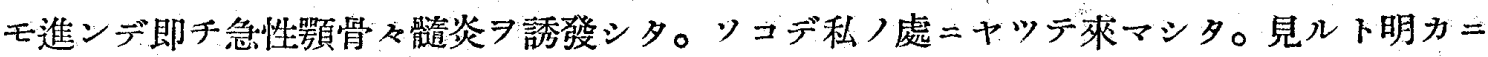

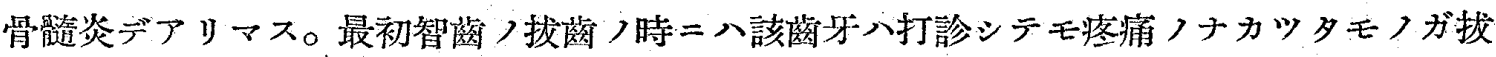
去後漸次增惡シテ私ガ芫マシタ時ニ八熱モ四十度习越シデ+マシタ。ソコデ取リアエズ顎 骨二沿フテ切開シ充分苦心シテ生命ダケハヤツトコサ取リトメマシタガ全矤骨八腐骨习形 成シ除去シナケレバナリマセンデシタ。ソノ人ハソノ篇メニ失業シタソウデアリマス。

本例二於テ皆サン八何ウオ考へニナリマスカ。私八敢へテ申シマスレバ智菌〉拔去八適 應デナカツタト云へマス。即チ打診スルモ疼痛ガナイノニ拔去シタノガ間違ツテ居ルト思 ヒマス。拔去ノ雼メ二病症惡化七ルモノト考へマス。本例八智亚難生ト思ヒマスガ此ノ如 キ例八非常ニ多イノデアリマス。智䔦難生ノ初期ニハ成ル可ク保存療法ガ宜シイ。適應デ ナイ拔萄入可成ク怚ム可キデアリマス。

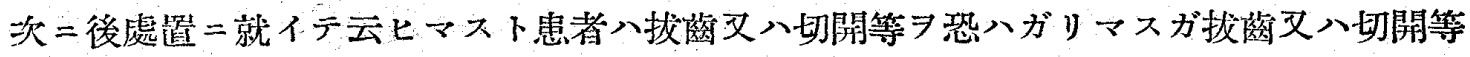

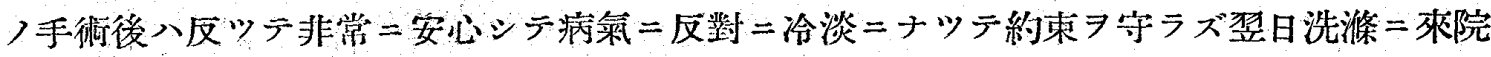
セズけタンポン!ヨシタマ、放舆シテ數日後經過シテ障碍ヨ起シテカラ初メテ來院シテサモ

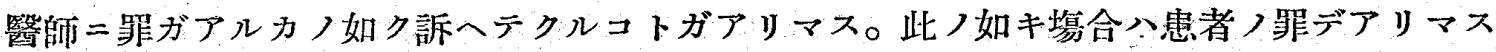
ガ併シ醫者ノ方デモ說明ガ不足ダツタトモ云ハレマス事ガアリマスカラロ療法ヨ充分ヤル 必要ガアルト思ヒマス。即チ是非翌日再來院ス可キ事习申シテ琪カネバナリマセン。

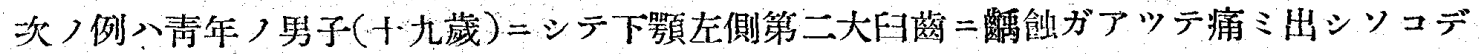

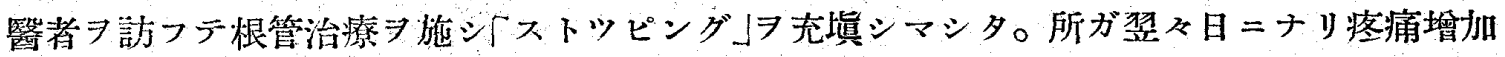
シ惡感戰慄フ來シマシタ。ソコデ醫者习訪ヒ「ストツピング」ヨ除去シテ貴ヒマシタトコロ

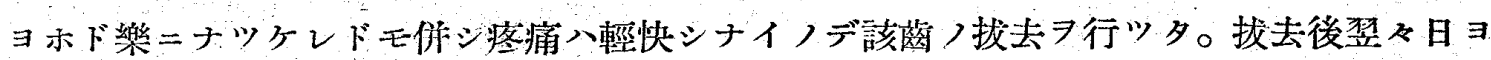
リ又ヒドクナリ顎下ヨリ耳前ニカケテ腫脹シ頸部マデモ及ンデキマス。ロ內フ喰查シテ見

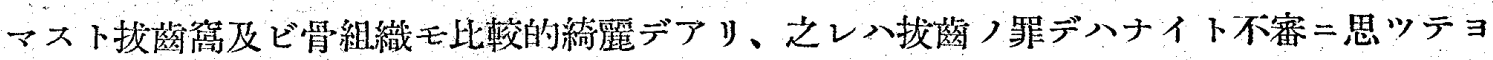

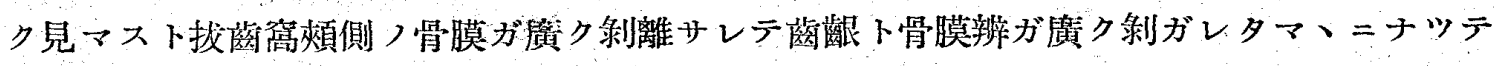
居ツテ消息子デ診查シテモ「タンポン」モセズ、ソノ中ニ八污物习澤山タメテキマシタ。恐

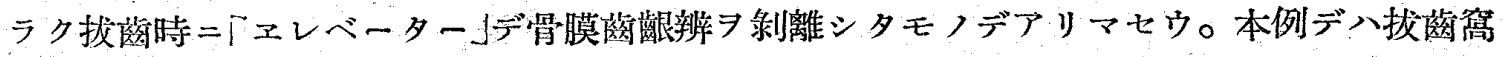

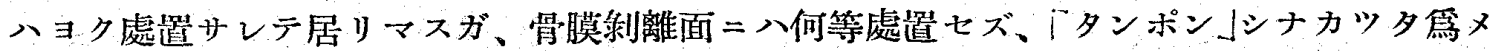

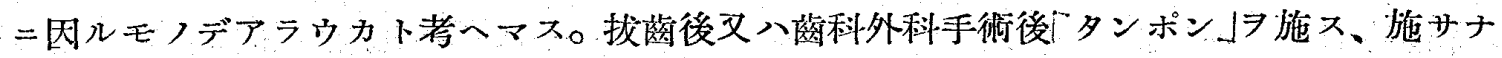
イト隨分ヤカマシク論議サレマスガ「タンポン」アヤツタカガ私八宜ロシイト考へマス。少 クトモ手術後タンポン」ヌスル事入醫師トシテノ手落ガナイ事ニナルト考へマス。

本例ノ如手正骨膜㸚離面ニ「タンポン」ヨ施ス可キデアツタト考へテ「タンポン」入極メテ 重要ナル後處置デアツテテ常ニ之レヨ行ツタカガ安全デアルト云へマス。

次 $=$ 注射 $=$ 就イテ八以前 $ヨ$ 急性炎症アル時八浸潤麻醉入不可デアツテ傳達麻醉ガ推賞 
サレマスガ、コノコト六近時ヨホド徹底シタ樣デアリマスガ今日私ノ述ベマスコトハコレ

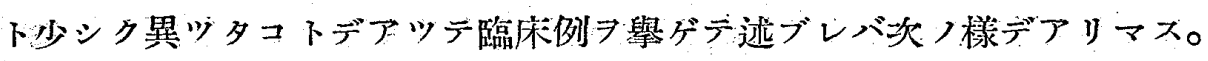

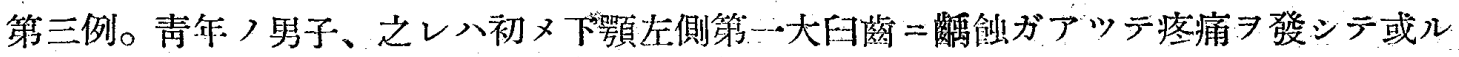

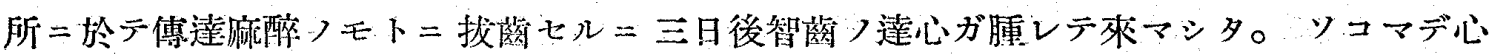

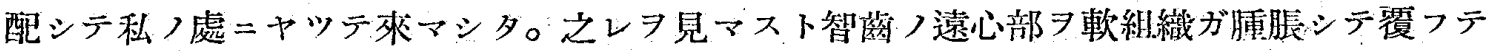
中マス。私八多分智落難生ノ初期ナラント思ヒ保倠療洼习施シテ歸宅セシメマシタ。然儿

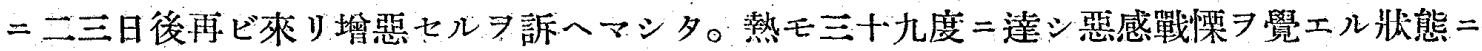

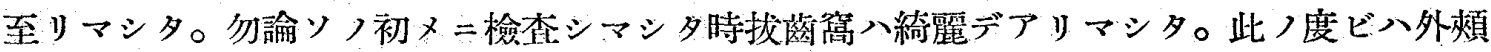

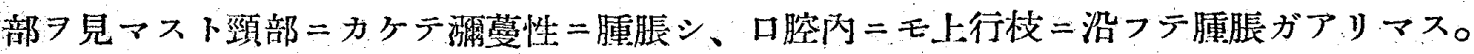
疼痛ハ强クナイガ牙關緊急ガ少シアリマシタ。故=此例タ私ガ誤診セルタ悟ツタノデ入院

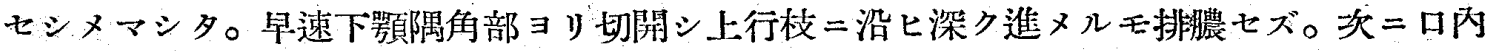

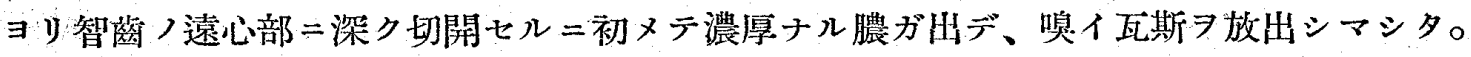
然シとレデモ輕快セズ其ノ後モ外聽道へ排膿シタリ等シテ項固デアリマシタ。其ノ人ハソ ンナ䉆メカ何ウカ知リマセンガ遂=肺尖加答兒习起シマシタ。

本例八注射液ノ不良或ヒハ注射針尖端ガ䓝垢等ニフレテ不潔ニナツ夕䉆メノ感染ナルカ 否カ分明シマセンガ注射ノ罪デハアルマイカト考へマス。カ、ル例八多イモノデ又此ノ祭 八切開 =ョリ常二特別ノ惡臭アル膿フ見マス。始息手段或ヒハ手術不足ノ塲合トシマシテ

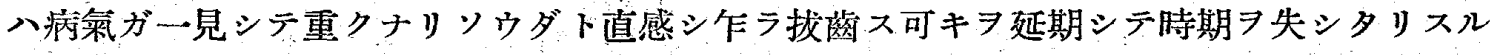
コトハマ、アルコトデアリマス。一例ヨ擧ゲマスト、

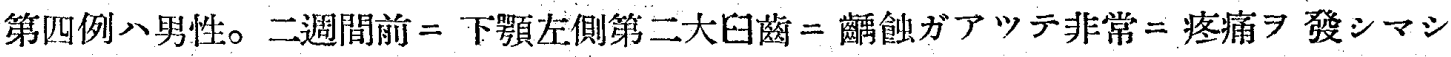
夕。或ル所デ診テ貰ツタ所急性炎症ガアルカラト云フテ拔落シナカツタ。其ノ後二三日對

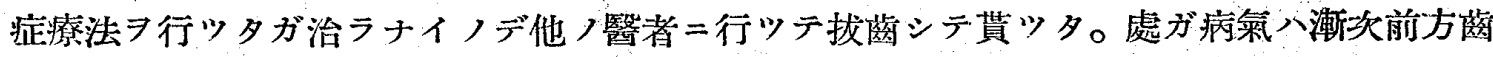

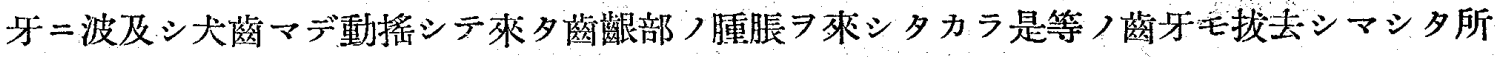
邆二反對側二モ及ビマシタ。ヨツテ私ノ診察ヨ公フタノデアリマス。之ヨ診マスルニ明カ

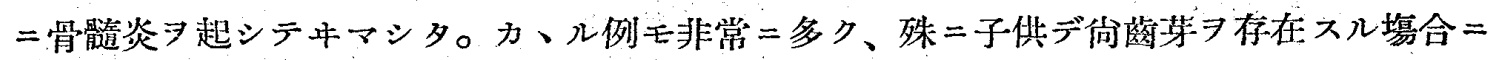
八殊二其〉营延ガ速カデアリマス。

カ、ル塲合八姫息手段ガ原因トナリヒドクナツタト考へラル、ノデアリマスガ、元來急 性根端性萄根膜炎ノ時ノ根端部ノ小ナル膿瘍ナル時ハウマク行ケバ根管ヨ貫通シタノミデ

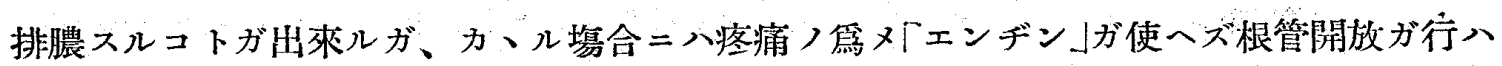

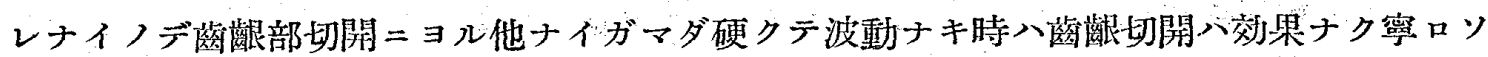
八切開二你フ危險ガ多イ。故二カ、ル際二八温瀿布 マスガ、ドウシテモイカナイ時ニハ早ク化膿ヨ限局サセテ波動 ルダケ溫メタ甫ガイ、。併シ每常必ズシモ溫メテハナラナイ。既二熱ガ三十九度斿至四十 
度ニモ昇儿時ハ骨髓炎つ危險ガ迫ツテホルト見ル可キデソレヨ冾溫ニ㣘ラズ濕布等シテオ

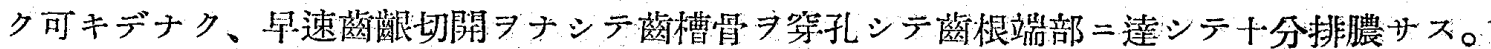

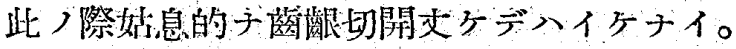

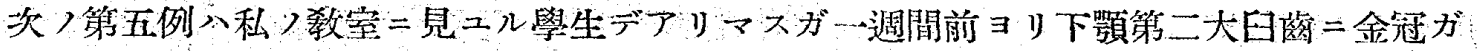
アリ疼痛 スノミデアリマンタ。邆二惡感戰慄ヨ起シ四ト度近クノ熱ヨ出シマシタガ外煩部ハマ外

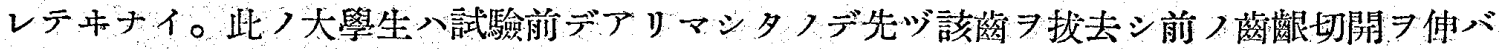
シ筲壁フ第孔シマシタルー膿ガ出シャシタ。柆日ヨリ速カニ輕快シマシタ。 以上ハ粗本子私ノ經驗デアリアス。皆サンノ參考ニナレバ幸思デアリマス。

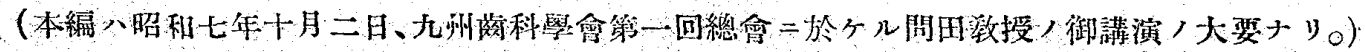

\section{拔去遥牙存求む！}

本校敎授站研究の參考用として 會 員諸君の御惠选を望し。 昭 和 8 年 3 月

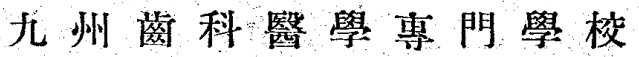
會 員 各 位 